\title{
UPDATING PETA TUTUPAN LAHAN MENGGUNAKAN CITRA SATELIT RESOLUSI TINGGI (Studi Kasus : Kecamatan Pakal, Kota Surabaya)
}

\author{
Alifah Noraini, Hepi Hapsari Handayani \\ Jurusan Teknik Geomatika, Fakultas Teknik Sipil dan Perencanaan \\ Institut Teknologi Sepuluh Nopember Surabaya (ITS) \\ Jl. Arief Rahman Hakim, Surabaya 60111 Indonesia \\ Email :hapsari@geodesy.its.ac.id
}

\begin{abstract}
Abstrak
Lingkungan merupakan suatu hal yang bersifat dinamis dan dapat berubah sewaktu - waktu.Sehingga dibutuhkan metode yang cepat dan akurat dalam meng-update data spasial untuk memonitoring perubahan lingkungan tersebut.Penelitian ini menggunakan teknologi penginderaan jauh. Data penginderaan jauh yang digunakan dalam penelitian ini adalah citra satelit WorldView 2 tahun 2012 dan Peta Garis Surabaya skala 1:5000 tahun 2002 hasil pemotretan foto udara. Daerah yang digunakan dalam penelitian ini adalah Kecamatan Pakal, Kota Surabaya.

Dalam pengolahan citra WorldView 2 didapatkan hasil identifikasi tutupan lahan di wilayah Kecamatan Pakal, Kota Surabaya yang didominasi oleh kelas tutupan lahan tambak, yakni seluas 756,476 Ha (40,62\%), dan kelas tutupan lahan terendah adalah kelas tutupan lahan waduk, yakni seluas 3,556 $\mathrm{Ha}$ (0,17\%). Dilakukan analisa perubahan tutupan lahan dari tahun 2002 hingga 2012. Hasil yang diperoleh dalam penelitian ini menunjukkan terjadinya perubahan luas yang paling signifikan di wilayah Kecamatan Pakal adalah meningkatnya kelas tutupan lahan permukiman, yakni sebesar 132,019 Ha (27,32\%). Serta menurunnya kelas tutupan lahan pertanian, semak belukar, dan tambak, yaitu seluas 145,559 Ha (30,12\%) pada kelas tutupan lahan pertanian, 60,628 Ha (12,55\%) pada kelas tutupan lahan semak belukar, dan 35,441 $\mathrm{Ha}(7,33 \%)$ pada kelas tutupan lahan tambak.
\end{abstract}

Hasil akhir dari penelitian ini adalah peta tutupan lahan tahun 2012 yang di-update menggunakan citra satelit WorldView 2 di wilayah Kecamatan Pakal, Kota Surabaya.

Kata Kunci :Updating Peta, Citra Satelit WorldView 2 2012, Tutupan Lahan

\section{PENDAHULUAN}

Lingkungan merupakan suatu hal yang bersifat dinamis dan dapat berubah sewaktu - waktu. Faktor terbesar yang mempengaruhi perubahan lingkungan adalah aktivitas manusia.Salah satu akibat dari perubahan lingkungan tersebut adalah perubahan tata guna lahan, terutama diwilayah perkotaan.Salah satu upaya untuk mengetahui perubahan lingkungan tersebut adalah mengupdate data spasial dari wilayah tersebut.Updating peta merupakan salah satu proses yang penting dilakukan oleh suatu negara sebagai monitoring kawasan wilayah dalam hal sosial, lingkungan, maupun ekonomi. Proses ini bertujuan untuk memperbaharui objek - objek yang terdapat dalam peta suatu wilayah dalam jangka waktu tertentu.

Updating peta di Indonesia dibutuhkan pada kota - kota besar, misalnya Kota Surabaya. Kota
Surabaya sebagai salah satu kota di Jawa Timur memiliki peran strategis pada skala regional sebagai pusat pelayanan kegiatan Indonesia Timur [1]. Oleh karena itu seluruh elemen wilayah Kota Surabaya dari tingkat kelurahan maupun kecamatan memiliki peran masing - masing sesuai dengan arah dan tujuan Rencana Tata Ruang Wilayah (RTRW) maupun Rencana Detil Tata Ruang Kota (RDTRK) Kota Surabaya.

Kecamatan pakal merupakan salah satu bagian dari Surabaya barat. Pada tahun 2012, salah satu pembangunan yang dilakukan oleh Pemerintah Kota Surabaya adalah pembangunan taman dan hutan kota. Pembangunan hutan kota akan dilakukan secara bertahap termasuk hutan kota yang akan dibangun di Kecamatan Pakal [2]. Sehingga dibutuhkan metode yang cepat untuk meng-update informasi peta. 
Dalam perkembangannya, penggunaan updating peta melalui citra satelit lebih banyak digunakan pada saat ini, misalnya di negara Afrika. Analisa teknik pemetaan konvensional menggunakan foto udara hitam putih dan lapangan di Afrika adalah lambat, rumit, serta mahal sehingga jika terus menerus dilakukan dirasa kurang terjangkau bagi negara tersebut[3]. Solusinya adalah menggunakan citra satelit dalam proses updatingnya.

WorldView 2 merupakan salah satu satelit yang diluncurkan oleh Digital Globe tahun 2009 dengan resolusi spasial tinggi, yaitu $2 \mathrm{~m}$ (multispektral) dan $0,5 \mathrm{~m}$ (pankromatrik). Satelit ini digunakan untuk mendukung aplikasi infrastruktur perencanaan, perencanaan kota, dan penaksiran dampak visual. Penggunaan satelit ini diharapkan dapat memberikan gambaran secara lebih detail terhadap interpretasi permukaan bumi dalam proses updating peta, khususnya untuk identifikasi perubahan lahan di wilayah Kecamatan Pakal, Kota Surabaya.

\section{TINJAUAN PUSTAKA}

\section{Updating Peta}

Informasi geografis dalam bentuk peta mengalami perubahan secara terus - menerus terutama didaerah perkotaan sehingga peta harus diperbaruhi.Salah satu teknik untuk updating peta adalah menggunakan teknik penginderaan jauh karena banyak satelit yang telah memiliki orbit saat ini.Salah satu aspek penting dalam updating peta adalah klasifikasi tutupan lahan ke tata guna lahan (Dekker, 2004).

Dasar kartografi untuk perencanaan regional adalah skala 1:10.000 dan semua negara dipetakan pada skala tersebut menggunakan metode tradisional dan survai udara. Produksi dan updating dari Regional Technical Map (RTM) merupakan tanggung jawab dari pemerintah dan masing - masing membuat aturan dan spesifikasi untuk produksi, meskipun aturan teknis negara, daerah, dan pemerintah daerah mencoba untuk mendefinisikan beberapa spesifikasi umum untuk keperluan umum topografi (Gianinetto, 2008).

\section{Interpretasi Manual dan Digital}

Interpretasi merupakan penilaian kualitatif pada data, yakni Interpretasi dapat diartikan sebagai penilaian secara kualitatif yaitu sifat data yang dapat dilihat secara visual atau bersifat semantic, obyek apa yang dipermukaan bumi yang diamati/dilihat, apakah obyek tersebut mengalami perubahan dan mengapa terjadi perubahan tersebut (Sukojo, 2012).

Interpretasi citra penginderaan jauh dapat dilakukan dengan dua cara, yaitu interpretasi secara manual dan interpretasi secara digital (Purwadhi, 2001).

a. Interpretasi secara manual

Interpretasi citra secara manual adalah interpretasi data penginderaan jauh yang mendasarkan pada pengenalan ciri (karakteristik) objek secara keruangan (spasial). Karakteristik objek yang tergambar pada citra dapat dikenali berdasarkan unsurunsur interpretasi seperti rona atau warna, bentuk, pola ukuran, letak dan asosiasi kenampakan objek.

b. Interpretasi secara digital

Interpretasi citra secara digital merupakan evaluasi kuantitatif tentang informasi spektral yang disajikan pada citra.Analisis digital dapat dilakukan melalui pengenalan pola spektral dengan bantuan komputer.

\section{METODE PENELITIAN}

Lokasi yang digunakan pada penelitian ini adalah Kecamatan Pakal, Kota Surabaya.

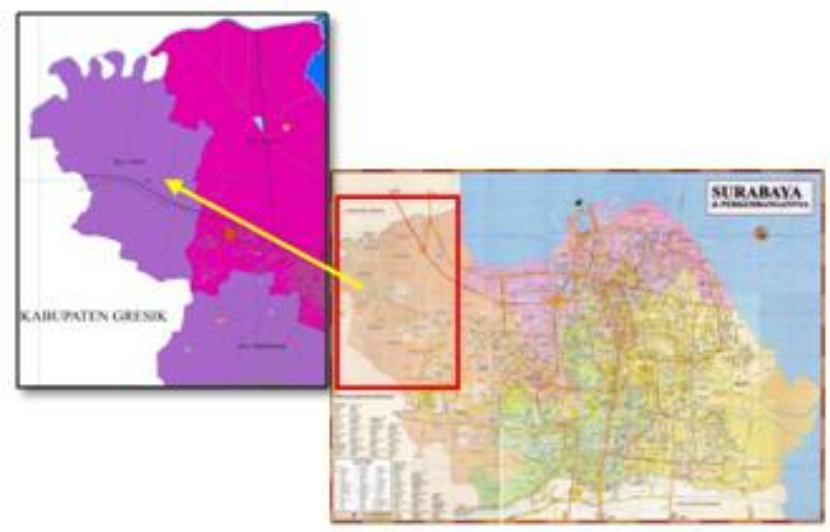

Gambar 1.Lokasi penelitian. ( BAPPEKO Kota Surabaya Tahun 2013) 
Dalam penelitian ini, Peta Garis skala 1:5.000 hasil foto udara tahun 2002 Kecamatan Pakal, Kota Surabaya dilakukan editing layer untuk mereduksi kesalahan akibatdijitasiotomatis. Pada citra satelit WorldView 2dilakukan pembuatan desain jaring untuk perhitungan desain Strenght of Figure (SoF) yang selanjutnya digunakan untuk proses koreksi geometrik. Pada proses koreksi geometric digunakan dua metode, yakni metode polinomial linier dan kuadratik. Setelah perhitungan SOF dan koreksi geometrik memenuhi syarat, selanjutnya adalah proses interpretasi.

Pada proses interpretasi citra digunakan dua metode, yaitu interpretasi citra secara manual digital. Interpretasi citra manual, yaitu menginterpretasi data citra berdasarkan pada ciri (karakteristik) objek secara spasial (keruangan).Setelah melakukan interpretasi manual kemudian dilakukan klasifikasi pada citra tersebut.Sedangkan pada interpretasi digital, seluruh objek pada citra diklasifikasikan berbasis piksel menggunakan klasifikasi terselia dengan pendekatan Maximum Likelihood Classification (MLC).Baik dalam interpretasi manual maupun digital, apabila hasil uji ketelitian tersebut $\geq 85 \%$ [8], maka klasifikasi tersebut dianggap benar. Jika proses interpretasi tersebut sudah benar maka dihasilkan Peta Tutupan Lahan Kecamatan Pakal, Kota Surabaya Tahun 2012.Pada Peta Tutupan Lahan Tahun 2012 dan Peta Garis Skala 1:5.000 Kecamatan Pakal, Kota Surabaya tahun 2002 dilakukan overlay untuk mengidentifikasi perubahan lahan pada Kecamatan Pakal, Kota Surabaya.

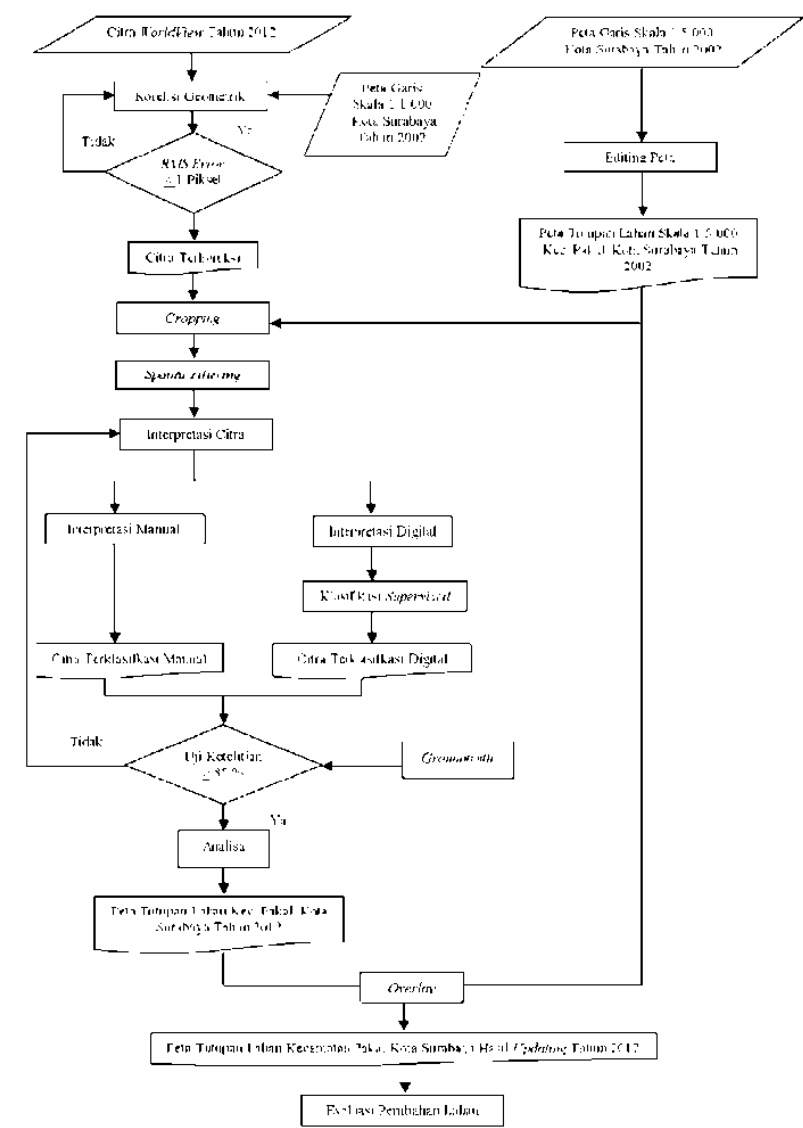

Gambar 2.Diagram alir pengolahan data.

\section{HASIL DAN PEMBAHASAN}

\section{Hasil Koreksi Geometrik Citra WorldView 2}

Pada koreksi geometrik citra satelit WorldView 2 digunakan 14 titik Ground Control Point (GCP)titik baik pada koreksi geometrik polynomial linier maupun kuadratik. Nilai RMS error untuk citra WorldView 2 tahun 2012 menggunakan metode polinomial linier sebesar 0,522669, sedangkan RMS error dengan menggunakan metode polynomial kuadratik adalah 0,418391 . Berikut merupakan tabel perbandingan dari kedua metode koreksi geometrik:

Tabel 1.

Hasil RMS error citra Worldview 2 tahun 2012

\begin{tabular}{lll}
\hline Titik & $\begin{array}{l}\text { RMS Metode Polinomial } \\
\text { Linier }\end{array}$ & $\begin{array}{l}\text { RMS Metode Polinomial } \\
\text { Kuadratik }\end{array}$ \\
\hline 1 & 0,1038 & 0,3536 \\
2 & 0,3306 & 0.0030 \\
3 & 0,4024 & 0,0090 \\
4 & 0,1107 & 0,1395 \\
5 & 0,3706 & 0,4112 \\
6 & 0,8720 & 0,6874 \\
\hline
\end{tabular}




\begin{tabular}{lll}
\hline 7 & 0,5238 & 0,5371 \\
8 & 0,5609 & 0,6420 \\
9 & 0,6419 & 0,6119 \\
10 & 0,6467 & 0,1463 \\
11 & 0,0155 & 0,2485 \\
12 & 0,7776 & 0,1588 \\
13 & 0,6526 & 0,4937 \\
14 & 0,4272 & 0,4872 \\
RMS rata & 0,522669 & 0,418391 \\
- rata & &
\end{tabular}

\section{Desain Jaring dan Perhitungan Strenght Of Figure (SOF)}

Berikut adalah desain jaring dan perhitungan SOF yang dilakukan pada citra WorldView 2 tahun 2012

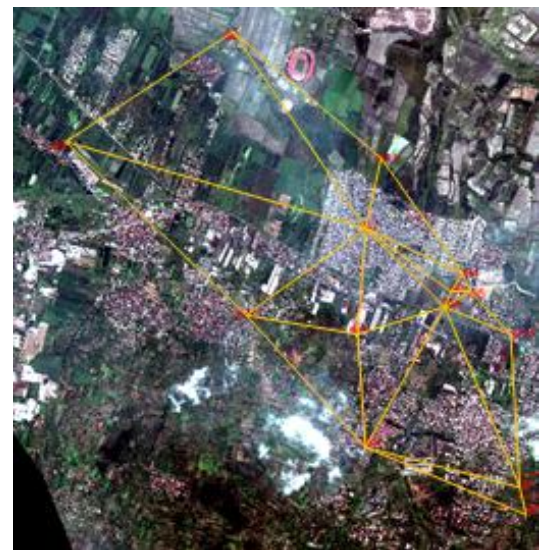

Gambar 3.Desain jaring citra satelit WordView 2 tahun 2012 Kecamatan Pakal.

$\begin{array}{ll}\text { Perhitungan SOF } & : \\ \text { Jumlah titik GCP } & : 14 \text { titik } \\ \text { Jumlah baseline } & : 29 \text { baseline } \\ \text { N ukuran } & : 86 \\ \text { N parameter } & : 58 \\ \text { U (Jumlah Parameter) } & : 28\end{array}$

$$
\begin{gathered}
\text { Faktor kekuatan jaringan }=\frac{\text { trace }\left[\mathrm{A}^{\mathrm{T}} \mathrm{A}\right]^{-1}}{\text { Jumlah Parameter }} \\
=0,2193
\end{gathered}
$$

Semakin kecil bilangan faktor kekuatan jaringan tersebut diatas, maka akan semakin baik konfigurasi jaringan dan sebaliknya [10].

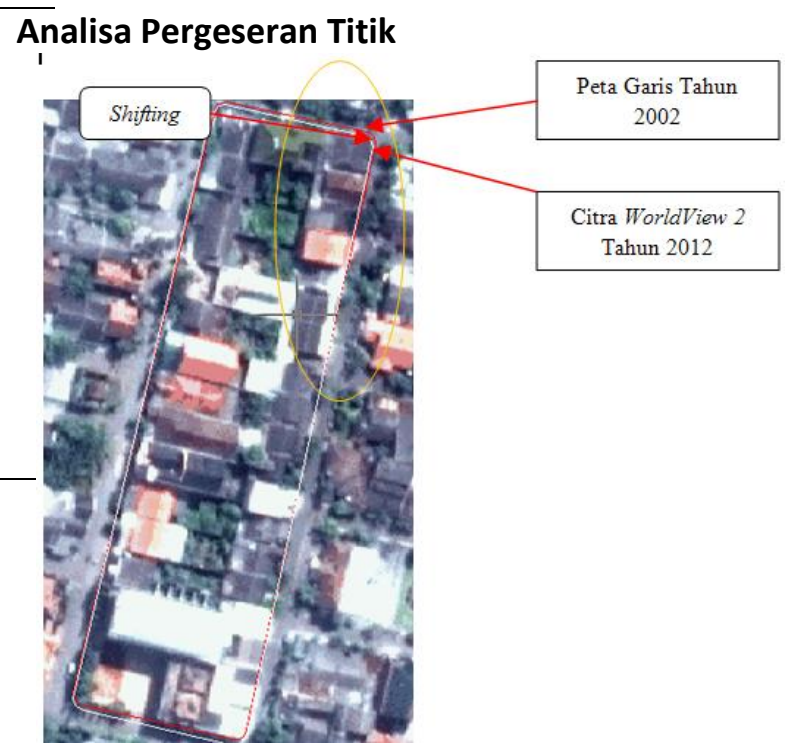

Gambar 4.Pergeseran titik di Kecamatan Pakal.

Pada proses updating peta Kecamatan Pakal, beberapa titik mengalami pergeseran. Adapun pergeseran titik pada objek tersebut tampak pada Gambar 4.

Pada Gambar 4, terdapat adanya shifting (jeda) antara titikruas jalan pada peta garis tahun 2002 dan titik yang didijit berdasarkan citra satelit WorldView 2 tahun 2012. Pergeseran titik tersebut diasumsikan karena perubahan titik dari tahun 2002 - 2012, misalnya pelebaran jalan maupun perubahan bangunan dari tahun ke tahun.

Pengamatan pergeseran dari titik - titik tersebut dilakukan pada beberapa ruas jalan secara acak (Gambar 4.) pada kedua hasil koreksi geometrik menggunakan metode polynomial linier dan kuadratik.Berdasarkan koordinat beberapa ruas jalan tersebut kemudian dihitung pergeseran tiap titik. Sebagai titik acuan adalah titik - titik yang diperoleh dari Peta Tutupan Lahan Kecamatan Pakal, Kota Surabaya Tahun 2012 yang di-update menggunakan citra Satelit WorldView 2. 


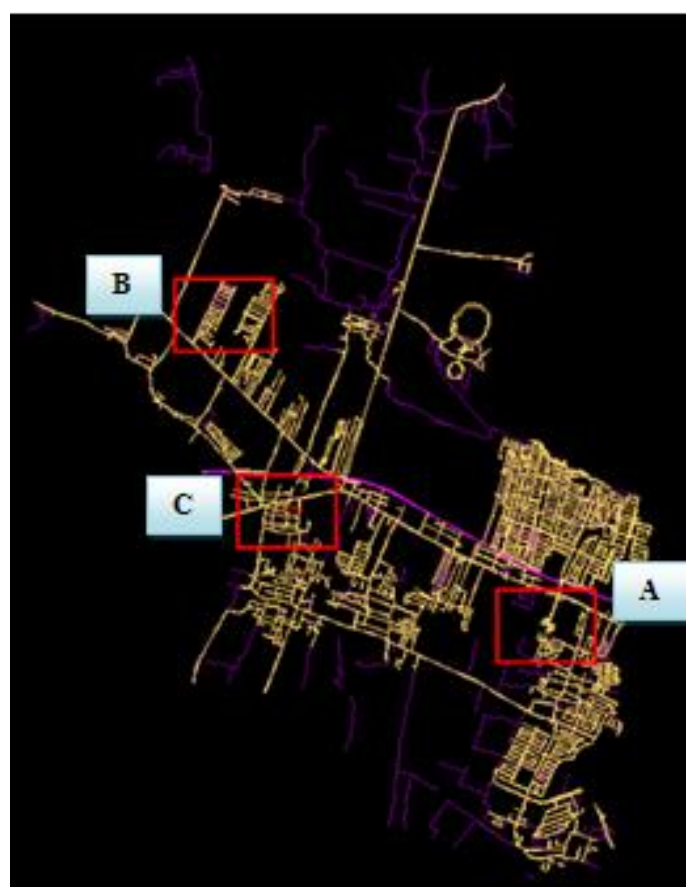

Gambar 5. Lokasi sample titik - titik pergeseran.

Yang dimaksud analisa pergeseran absis $(x)$ yaitu membandingkan masing - masing nilai absis $(x)$ koordinat titik dari hasil dijitasi citra satelit WorldView 2 tahun 2012 dan foto udara tahun 2002. Berdasarkan hasil perhitungan pergeseran absis, diketahui bahwa rata - rata nilai pergeseran absis menggunakan metode polynomial linier adalah -0,3031 m.Sedangkan untuk analisa pergeseran ordinat $(\mathrm{y})$ merupakan perbandingan antara masing - masing nilai ordinat $(\mathrm{y})$ koordinat titik dari hasil dijitasi citra satelit WorldView 2 tahun 2012 dan foto udara tahun 2002.

Berdasarkan hasil perhitungan pergeseran ordinat diketahui bahwa rata - rata nilai pergeseran ordinat menggunakan metode polynomial linier adalah 0,6106 m.

Berdasarkan hasil perhitungan pergeseran absis, diketahui bahwa rata - rata nilai pergeseran absis menggunakan metode polynomial kuadratik adalah -2,2589 $\mathrm{m}$. Sedangkan untuk perhitungan pergeseran ordinat diketahui bahwa rata - rata nilai pergeseran ordinat menggunakan metode polynomial kuadratik adalah $-1,9429 \mathrm{~m}$.

Dari hasil perhitungan pergeseran absis maupun koordinat, pergeseran koordinat menggunakan metode koreksi geometric polynomial kuadratik lebih besar dari pergeseran koordinat menggunakan metode koreksi geometric polynomial kuadratik. Hal ini dimungkinkan bahwa wilayah Kecamatan Pakal memiliki kondisi permukaan yang relatif datar, sehingga kurang cocok digunakan metode koreksi geometrik polynomial kuadratik.Pada proses selanjutnya, yakni interpretasi baik manual maupun dijital digunakan citra hasil koreksi geometric mengunakan metode polynomial linier.

\section{Hasil Uji Ketelitian Interpretasi Citra}

a. Uji ketelitian interpretasi manual

Dalam intepretasi manual ini diambil sebanyak 44 titik yang didapatkan dari hasil groundtruth. Terdapat kesalahan sebanyak 1 titik, sehingga:

$$
\begin{aligned}
\mathrm{JKI} & =43 \\
\mathrm{JSL} & =44 \\
\mathrm{KI} & =\frac{\mathrm{JKI}}{\mathrm{JSL}} \times 100 \% \\
\mathrm{KI} & =\frac{43}{44} \times 100 \% \\
& =97,73 \%
\end{aligned}
$$

Dengan hasil Ketepatan Interpretasi (KI) manual 97,73\% pada citra satelit WorldView 2 2012, maka ketepatan interpretasi manual dianggap benar karena telah memenuhi toleransi, yaitu $>85 \%$.

\section{b. Uji ketelitian interpretasi digital}

Uji ketelitian interpretasi digital ini menggunakan penilaian klasifikasi secara otomatis, yakni post classification.Dengan hasil Ketepatan Interpretasi (KI) digital 85,5841\%, maka ketepatan interpretasi digital ini dianggap benar karena telah memenuhi toleransi, yakni $>85 \%$.

\section{Analisa Perbandingan Hasil Interpretasi}

Adapun perbandingan luasan dari hasil interpretasi baik secara manual maupun dijital disajikan dalam tabel berikut:

Tabel 2.

Perbandingan luas hasil interpretasi manual, dijital, dan tahun 2002

\begin{tabular}{lllll}
\hline No & \multicolumn{3}{c}{ Luas (Ha) } & \\
& $\begin{array}{l}\text { Kelas Tahan } \\
\text { Tatupan }\end{array}$ & $\begin{array}{l}\text { Tahun } \\
2002\end{array}$ & $\begin{array}{l}\text { Tahun 2012 } \\
\text { Interpretasi } \\
\text { Manual }\end{array}$ & $\begin{array}{l}\text { Interpretasi } \\
\text { Dijital }\end{array}$ \\
\hline 1 & Pertanian & 572,674 & 427,115 & 206,971 \\
2 & Semak Belukar & 121,591 & 60,963 & 202,753 \\
3 & Padang Rumput & - & 49,934 & 446,897 \\
\hline
\end{tabular}




\begin{tabular}{|c|c|c|c|c|}
\hline 4 & Permukiman & 90,552 & 222,571 & 153,237 \\
\hline 5 & Bangunan Industri & - & 31,907 & 114,820 \\
\hline 6 & Lahan Terbangun & - & 10,234 & 7,838 \\
\hline 7 & $\begin{array}{ll}\text { Lahan } & \text { Tidak } \\
\text { Terbangun } & \end{array}$ & - & 3,191 & 73,906 \\
\hline 8 & Jalan & 285,373 & 286,778 & 109,331 \\
\hline 9 & Tambak & 791,917 & 756,476 & 293,086 \\
\hline 10 & Sungai & - & 9,382 & 129,414 \\
\hline 11 & Waduk & - & 3,556 & 89,370 \\
\hline 12 & $\begin{array}{ll}\text { Area } & \text { tak } \\
\text { terklasifikasi }\end{array}$ & - & - & 34,484 \\
\hline Tota & & $1.862,107$ & $1.862,107$ & $1.862,107$ \\
\hline
\end{tabular}

Pada tabel dan grafik diatas diketahui bahwa luas klasifikasi tutupan lahan hasil interpretasi dijital tidak sebanding dengan luas tutupan lahan tahun 2002, sedangkan luas klasifikasi dari interpretasi manual hampur sama dengan luas tutupan lahan tahun 2002. Hal ini disebabkan karena luas klasifikasi tutupan lahan yang dihasilkan pada interpretasi dijital mengacu pada nilai per piksel (berdasarkan metode objek berbasis piksel). Pada pemrosesan citra dan metode klasifikasi supervised MLC, piksel yang memiliki kemiripan spektral dan panjang gelombang maksimum dari setiap densitas piksel, seperti area terbangun dan area tidak terbangun pada peta tematik (Hasyim, 2012).

Selain itu, pada proses interpretasi dijital jumlah kelas yang digunakan juga mempengaruhi hasil dari klasifikasi objek tersebut. Semakin banyak kelas yang digunakan, maka semakin detil interpretasi yang dihasilkan. Akan tetapi, detil interpretasi yang dihasilkan dengan mengacu pada klasifikasi berbasis piksel dimungkinkan terdapat piksel yang masuk ke kelas lain. Sehingga dalam updating tutupan lahan ini mengacu pada hasil klasifikasi tutupan lahan yang dihasilkan dari interpretasi manual yang telah dilakukan uji ketelitian klasifikasi.

\section{Tutupan Lahan}

Untuk mengetahui perubahan tutupan lahan kondisi Kecamatan Pakal dengan melakukan overlay pada peta tutupan lahan tahun 2002 dan peta tutupan lahan tahun 2012 dari citra satelit WorldView 2.

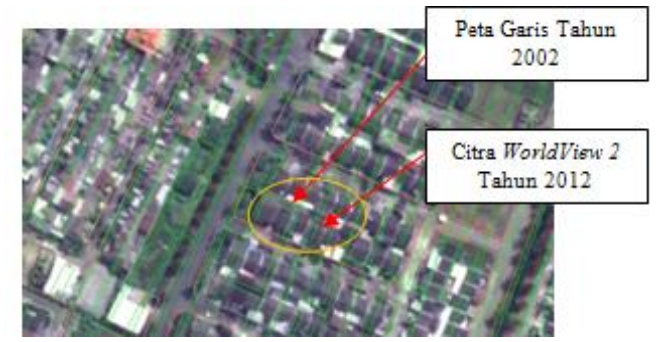

Gambar 6.Perubahan objek di Kecamatan Pakal.

Pada gambar diatas, tampak bahwa adanya perubahan objek pada Kecamatan Pakal.Perubahan objek tersebut didominasi karena aktivitas manusia. Salah satu contohnya adalah (Gambar 6) pada tahun 2002 kawasan tersebut merupakan tutupan lahan pertanian (garis berwarna hijau) akan tetapi pada tahun 2012 kawasan tersebut berubah menjadi permukiman dan jaringan jalan. Dalam proses updating peta ini mengacu pada citra satelit WorldView 2 sehingga untuk dijitasi objek lahan pertanian (garis berwarna hijau) dihapus yang digantikan oleh dijitasi objek permukiman dan jaringan jalan.

Berikut adalah kondisi tutupan lahan Kecamatan Pakal tahun 2012 diperlihatkan dalam tabel perhitungan luas tutupan lahan sebagai berikut:

Tabel 3.

\begin{tabular}{lll}
\multicolumn{3}{l}{ Luas tutupan lahan Kecamatan Pakal tahun $\mathbf{2 0 1 2}$} \\
\hline No & Kelas Tutupan Lahan & Luas (Ha) \\
\hline 1 & Pertanian & 427,115 \\
2 & Semak Belukar & 60,963 \\
3 & Padang Rumput & 49,934 \\
4 & Permukiman & 222,571 \\
5 & Bangunan Industri & 31,907 \\
6 & Lahan Terbangun & 10,234 \\
7 & Lahan Tidak Terbangun & 3,191 \\
8 & Jalan & 286,778 \\
9 & Tambak & 756,476 \\
10 & Sungai & 9,382 \\
11 & Waduk & 3,556 \\
Total & 1862,108 \\
\hline
\end{tabular}


Grafik luas tutupan lahan Kecamatan Pakal Tahun 2012 dapat dilihat sebagai berikut:

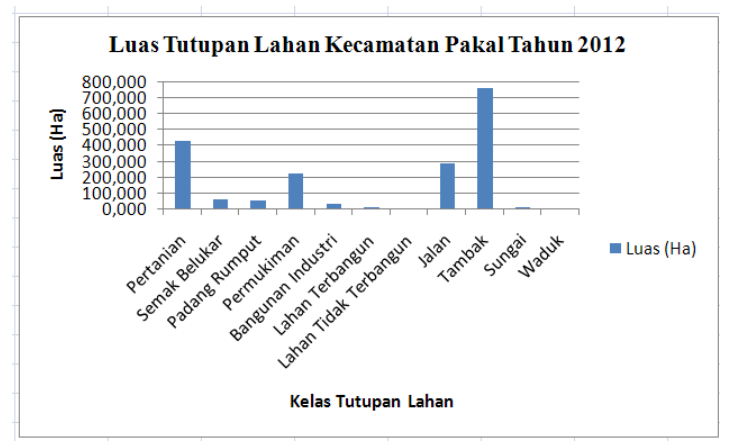

Gambar 7.Grafik luas tutupan lahan Kecamatan Pakal tahun 2012.

Kondisi tutupan lahan Kecamatan Pakal Tahun 2012 sebagian besar didominasi oleh tambak karena wilayah ini termasuk pada pesisir utara Kota Surabaya, yaitu seluas $756,476 \mathrm{Ha}(40,62 \%)$ pada tahun 2012. Selain litu, hampir seperempat lahan dari wilayah kecamatan ini, yakni seluas $427,115 \mathrm{Ha}$ (22,94\%) didominasi oleh lahan pertanian.

Sedangkan pada kondisi tutupan lahan Kecamatan Pakal tahun 2002 diilustrasikan pada tabel berikut:

Tabel 4.

Luas tutupan lahan Kecamatan Pakal tahun 2002

\begin{tabular}{lll}
\hline No & Kelas Tutupan Lahan & Luas $(\mathrm{Ha})$ \\
\hline 1 & Pertanian & 572,674 \\
2 & Semak Belukar & 121,591 \\
3 & Bangunan & 90,552 \\
4 & Jalan & 285,373 \\
5 & Tambak & 791,917 \\
Total & & 1862,107 \\
\hline
\end{tabular}

Grafik luas tutupan lahan Kecamatan Pakal Tahun 2002 dapat dilihat sebagai berikut:

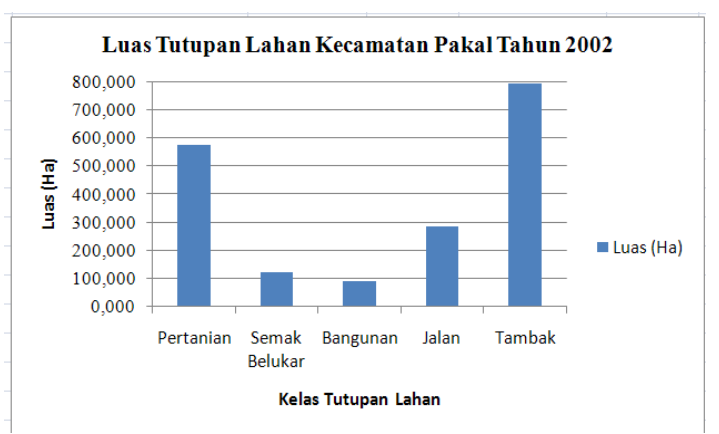

Gambar 8.Grafik luas tutupan lahan Kecamatan Pakal tahun 2002.
Pada tahun 2002, Kecamatan Pakal lebih dari separo didominasi oleh kelas tutupan lahan tambak, yakni seluas 791,917 Ha (42,53\%). Sedangkan pada luas terendah merupakan tutupan lahan pada kelas bangunan, yakni sebesar $90,552 \mathrm{Ha}(4,86 \%)$.

Berikut merupakan penghitungan luas perubahan tutupan lahan Kecamatan Pakal tahun 2002-2012 dengan menggunakan tiga kelas utama yaitu, vegetasi, bangunan, dan perairan:

Tabel 5.

Penghitungan luas perubahan tutupan lahan Kecamatan Pakal, Kota Surabaya tahun 2002-2012

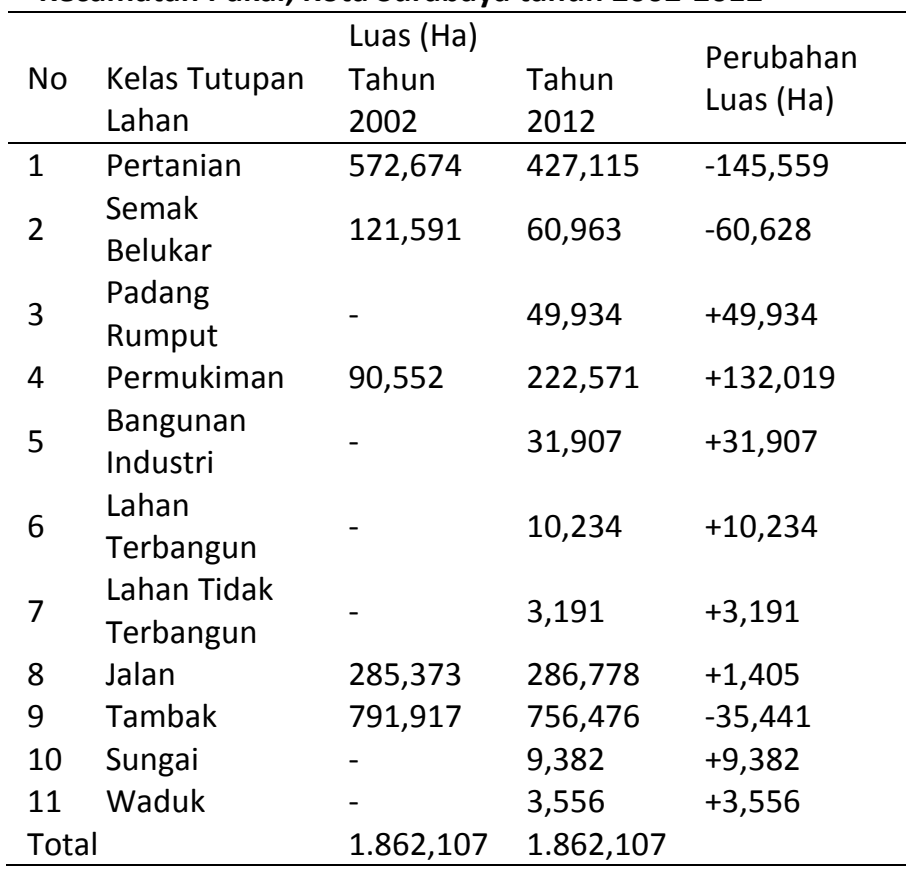

Grafik perubahan luas tutupan lahan Kecamatan Pakal, Kota Surabaya Tahun 2002-2012 dapat dilihat sebagai berikut:

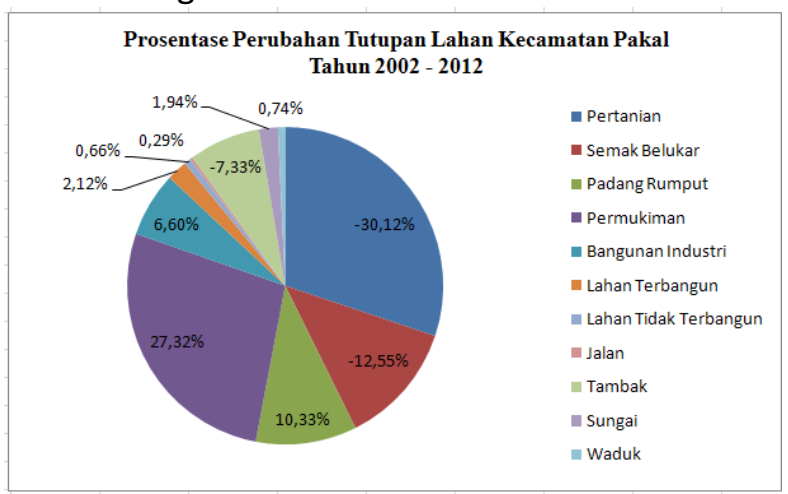

Gambar 9.Prosentase perubahan luas tutupan lahan Kecamatan Pakal tahun 2002-2012. 
Dari keseluruhan perubahan tutupan lahan Kecamatan Pakal dari tahun 2002-2012 kelas tutupan lahan yang mengalamai perubahan tutupan lahan paling signifikan adalah kelas pertanian, yakni menurun sebesar 145,559 $\mathrm{Ha}$ $(30,12 \%)$.

Berkurangnya kelas tutupan lahan pertanian, semak belukar dan tambak, sebagian besar telah menjadi tutupan lahan bangunan, yakni berubah sebesar 132,019 Ha $(27,32 \%)$ pada permukiman, $31,907 \mathrm{Ha}(6,60 \%)$ pada bangunan industri, $10,234 \mathrm{Ha}$ pada lahan terbangun $(2,12 \%)$, dan $3,191 \mathrm{Ha}(0,29 \%)$ pada lahan tidak terbangun.

\section{KESIMPULAN}

Berdasarkan hasil penelitian mengenai updating peta menggunakan citra satelit WorldView 2, maka didapatkan beberapa kesimpulan akhir yaitu:

a. Berdasarkan hasil identifikasi tutupan lahan menggunakan citra WorldView 2 tahun 2012, tutupan lahan di wilayah Kecamatan Pakal, Kota Surabaya didominasi oleh kelas tutupan lahan tambak, yakni seluas 753,559 $\mathrm{Ha}$ $(48,21 \%)$, lebih dari seperempat luasannya didominasi oleh kelas tutupan lahan pertanian seluas $427,115 \mathrm{Ha}(27,33 \%)$, sedangkan kelas tutupan lahan terendah adalah kelas tutupan lahan tambak, yakni seluas 3,556 Ha (0,23\%).

b. Perubahan luas yang paling signifikan dari tahun 2002 hingga tahun 2012 di wilayah Kecamatan Pakal adalah meningkatnya kelas tutupan lahan bangunan, yakni sebesar 177,958 Ha (69,64\%). Sedangkan pada kelas tutupan lahan pertanian dan semak belukar mengalami penurunan luasan, yakni seluas 0,062 Ha (0,02\%) pada kelas tutupan lahan pertanian dan 29,894 Ha (11,70\%) pada kelas tutupan lahan semak belukar. Penurunan perubahan luasan pada kelas tutupan lahan ini tidak dapat diidentifikasi secara maksimal karena pada Peta Tutupan Lahan tahun 2002 terdapat area yang tidak terdijitasi.

\section{DAFTAR PUSTAKA}

Badan Perencanaan Pembangunan. 2012 . RPJMD (Rencana Pembangunan Jangka Menengah
Daerah) Daerah Kota Surabaya Tahun 2010 - $2015 \quad<U R L$ :http://www.surabaya.go.id/dinamis/?id=3 721>, diakses pada tanggal 12 Maret 2013 pukul $17.00 \mathrm{BBWI}$.

Pandia, Agnes Swetta Br. 2012. "Surabaya Terus Menambah Hutan Kota". Kompas (Surabaya), 24 Juni. <URL: http://bisniskeuangan.kompas.com/read/2 012/06/24/11413961/Surabaya.Terus.Men ambah.Hutan.Kota>, diakses pada tanggal 15 Maret 2013 pukul 14.00 BBWI.

Khamala, E. and Ottichilo, W. 2002. "Map Updating Using High Resolution Satellite Imagery A Case of the Kingdom of Swaziland". The International Archive of the Photogrammetry, Remote Sensing and Spatial Information Sciences, Vol.XXXIV, Part 6/W6 : 89-92.

Dekker, R. J. 2004. “Object-Based Updating of Land-Use Maps of Urban Areas Using Satellite Remote Sensing". Geoinformatics 2004, Proceeding 12th International Conference on Geoinformatics - Geospatial Information Research : Bridging the Pasific and Atlantic, 7-9 June 2004. University of Gävle, Sweeden.

Gianinetto, Marco. 2008. “Updating Large Scale Topographic Databases in Italian Urban Areas with Submater Quickbird Images". Diedit oleh : Paul Cross. International Journal of Navigation and Observation, Hindawi Publishing Corporation.

Sukojo, Bangun Muljo. 2012. Penginderaan Jauh: Dasar Teori dan Terapan. Surabaya: Itspress.

Purwadhi, F. Sri Hardiyanti. 2001. Interpretasi Citra Digital. Jakarta: Grasindo.

Andreson, James R., Hardy, Ernest E., Roach, John T., and Witmer, Richard E. 1976. A Land Use and Land Cover Classification System for Use with Remote Sensor Data. Washington : United States Government Printing Office.

Abidin, Hasanuddin Z., Jones, Andrew, dan Kahar, Joenil. 2002. Survei dengan GPS. Jakarta : Pradnya Paramita.

Hasyim, Abdul Wahid., Hariyanto, Teguh., Taufik, M., and Sulistyarso, Haryo. 2011. "Urban Land Use Change Analysis Using Temporal Multispectral Imagery and Image Difference". International Journal of Academic, Vol. 3 No. 3 May, 2011: 246251. 


\section{LAMPIRAN}

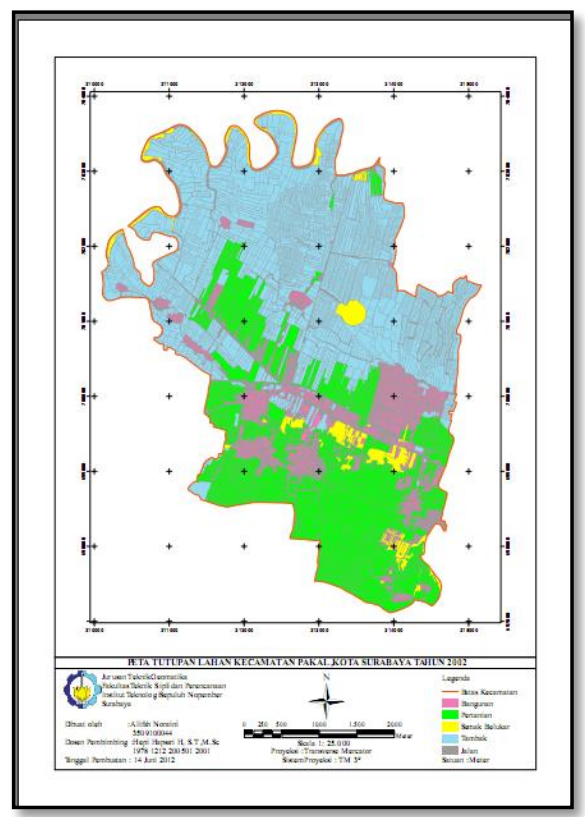

Gambar 9. Peta tutupan lahan tahun 2002

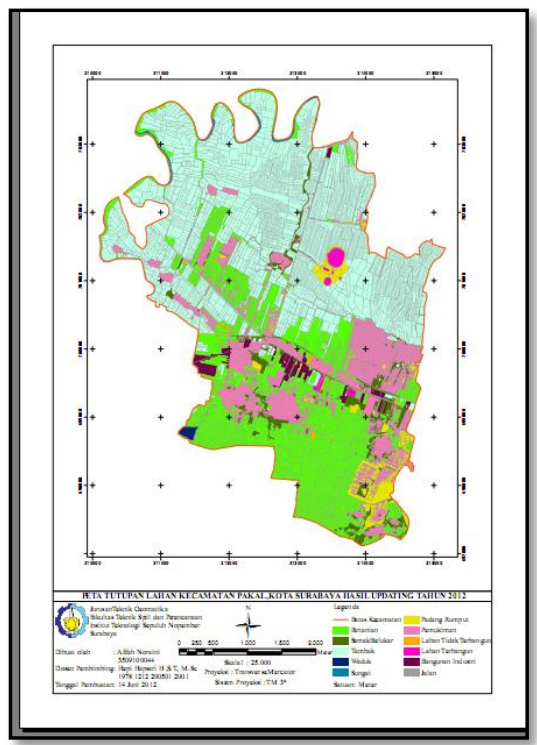

Gambar 10. Peta tutupan lahan tahun 2012 hasil updating 